Faculty of Humanities and Social Sciences

University of Zagreb

Croatia

\title{
CASSANDRA FEDELE AND HER DALMATIAN CORRESPONDENTS
}

\begin{abstract}
The paper analyses the written correspondence between Cassandra Fedele, a renowned Venetian woman humanist from the late $15^{\text {th }}$ and early $16^{\text {th }}$ century, and three lesser-known Dalmatian humanists - Benedikt Mišulić from Pag, Ambroz Mihetić from Šibenik and Pavao Paladinić from Hvar. The first two exchanged letters with Fedele; from their correspondence only one of her letters to Mišulić and one to Mihetić have been preserved, as well another longer letter Mihetić sent to the Venetian humanist. The analysis of these letters primarily focuses on the details of their content, which allow for the reconstruction of the cultural climate in Dalmatian cities and broadens our understanding of its protagonists and the literary communication between the two Adriatic coasts. The paper also notes that Fedele mentions Mišulić in at least two other letters in which she is probably pleading for a position at the Spanish court. On the other hand, Paladinić dedicated a laudatory poem in Latin to Fedele in which he praises her erudition. Apart from widening our knowledge of the three Dalmatian humanists and their contacts with Fedele, the paper also analyses specific rhetorical strategies the texts employ. In the conclusion the paper considers the possibility that the addressee of two of Fedele's letters might have been a humanist from Kotor named Bernard Pima. The assumption is nevertheless dismissed, but Pima is credited with the authorship of two overlooked poems from a manuscript in the Marciana Library.
\end{abstract}

Keywords. - Cassandra Fedele, women in European humanism, Dalmatian humanism, Benedikt Mišulić, Ambroz Mihetić, Pavao Paladinić, Bernard Pima, humanist epistolography

Cassandra Fedele, a Venetian woman humanist who achieved fame in the last decades of the $15^{\text {th }}$ and at the beginning of the $16^{\text {th }}$ century, had humanists as correspondents, friends and admirers even on the eastern coast of the Adriatic. Scholarly literature contains sporadic mentions of individual Dalmatians communicating with Fedele, but the evidence is incomplete, usually only marginally expressed, in discussions of other issues. Having decided to write on this topic I sought to contribute not only to the understanding of the life and work of Cassandra Fedele, but to improved understanding of early Dalmatian humanism 
as well. Until recently, two or three decades ago, early humanism in Dalmatian towns - meaning humanism in the second half of the $15^{\text {th }}$ century - was relatively poorly researched, while today, owing to recent work by a number of Croatian classicists and literary historians, knowledge of the period is more extensive. ${ }^{1}$ Thus we know much more about intellectuals and literary culture in Dalmatia of the day, about manuscripts containing Latin texts from ancient Roman and early Renaissance sources, about their distribution, circulation and copying, about literary communication between the two coasts of the Adriatic, and generally, about the process of studia humanitatis taking root and spreading in Dalmatia. My short discussion should contribute to recovering the cultural atmosphere of the day and add to knowledge about its participants. I believe that such an augmentation of our knowledge cannot be irrelevant, even if it is only minute details that are uncovered, because if there is a time in the cultural history of the Croatian coast when we can speak of important beginnings, about a genuine restructuring of literary culture, it is precisely the middle and third quarter of the $15^{\text {th }}$ century. Thus, in addition to Cassandra Fedele, the article shall deal with early Dalmatian humanists, individuals who may not have left great literary works, but have helped establish the preconditions for their creation. The corpus of such knowledge is not only relevant for the history of Croatian humanism, but also for improved understanding of the emergence of somewhat younger vernacular Renaissance literature in Dubrovnik and Dalmatia. Individuals like those to be mentioned here actively participated in forming an evolutionary, dynamic literary life and cultural atmosphere. In small Dalmatian towns their wide humanistic education and activities set up aesthetic criteria, standards and expectations fit for the international literary 'republic', and this new level of intellectual and cultural life paved the way for modern, vernacular-language Renaissance literature at the end of the $15^{\text {th }}$ century.

Cassandra Fedele (Lat. Fidelis) was born in Venice in 1465. She was a renowned educated woman of her time, the most famous female humanist in Europe at the end of the $15^{\text {th }}$ century and the beginning of the $16^{\text {th }}$, and one of the few educated women allowed to display her learning in public. She was often invited to appear at public occasions, for example to participate in humanistic discussions or give speeches, often before the Doge of Venice and Venetian aristocracy, sometimes even in university circles. At the turn of the $15^{\text {th }}$ into the $16^{\text {th }}$ century Fedele was so well known, so much talked of and written about that she could be considered a celebrity of the day. She made her reputation as a learned person at a very young age; her father provided a thorough private education, so already at the age of twelve she had mastered Greek and Latin, and was well acquainted with the works of the

${ }^{1}$ English readers may see the following recent works: Novaković (2000); Lučin (2014); Novaković (2014); Jovanović (2017); Špoljarić (2017). 
classical authors. ${ }^{2}$ She then turned, by her own admission not without difficulties, to the study of philosophy and science. The fame of Cassandra Fedele rapidly spread across Italy and Europe, and many wanted to communicate with such an attraction - an extremely learned young woman. Thus Fedele began corresponding with numerous renowned humanists and writers of the late $15^{\text {th }}$ century, such as Angelo Poliziano, Marcantonio Sabellico, Panfilo Sasso, Giovanni Aurelio Augurello, Pico della Mirandola, as well as eminent church dignitaries and rulers, such as Pope Alexander VI, the patriarch of Aquileia Domenico Grimani, the Spanish king and queen Ferdinand II of Aragon and Isabella of Castile, the French king Louis XII, the duke of Milan Ludovico Maria Sforza, and Beatrice d'Este. Three of her speeches, a number of verses in Latin and a fairly extensive epistolary have been preserved. Like many other humanists, Fedele carefully preserved her correspondence because letters represented a form of intellectual autobiography and many were expected to be, once sent, copied and entered into circulation among learned readers. This young Venetian humanist cemented her fame with a ceremonial speech delivered at the university of Padua in 1487 at her cousin Bertuccio Lamberti's graduation ceremony. The speech was printed as incunabula three times, one of these in Nürnberg, only two years after it was initially given, which clearly testifies to the speed with which her reputation as a learned woman was spreading. The three preserved speeches and the great majority of her letters (over a hundred) were published together in 1636 in Padua as Clarissimae feminae Cassandrae Fidelis Venetae epistolae et orationes posthumae, nunquam antehac editae, a book edited by the polyhistor Giacomo Filippo Tomasini. Certain data from her letters and claims by older biographers indicate that Fedele wrote more Latin verses than have been preserved, as well as a number of treatises which are now lost (for example De scientiarum ordine, Virorum illustrium encomia, Digressioni morali).

Cassandra Fedele's fame and popularity did not last long. The few educated women there were in the then Western European societies would, in time, when grown up, be faced with a choice - to marry and devote themselves to family life or to turn to their faith completely, which almost exclusively meant going to a nunnery. ${ }^{3}$ In the relentless patriarchal, masculine intellectual world women were not allowed to study at a university or get employed there, which effectively meant that it would have been very difficult for them to engage in scholarship

${ }^{2}$ Literature on Cassandra Fedele is extensive, indeed. I shall single out a few works which I consider most helpful for acquiring basic information about her life and oeuvre: Simonsfeld (1890); Simonsfeld (1893); Cavazzana (1906); King (1976); King (1980); King and Rabil (1983: 21-30, 48-50, 69-77, 87, 88, 126-129); Robin (1994); Pignatti (1995); Robin (1995); Robin (2000); Robin (2002); Robin (2007); A. Fedele (2010); King (2014); Meyer (2014: 89-97).

${ }^{3}$ For more information see the above mentioned King (1976) and King (1980). See also Kristeller (1980) and Jardine (1985). 
permanently. Thus in 1499 Fedele opted for marriage, late in life as was deemed then, which quite expectedly overlaps with the end of her commitment to scholarship and literature. Widowed in 1520, she resumed her youthful interests, and being childless, she continued to reside with her family. For the rest of her life she struggled with poverty, forgotten by the public and her homeland which had been so proud of her. She died in 1558 at a very advanced age; yet, following the years of oblivion, she was buried with full state honours. Interestingly, in 1556 Venetian authorities asked Fedele, then 91 years old, to deliver a speech of welcome for Bona Sforza, Queen of Poland, who was travelling through Venice at the time.

For most of the twentieth century this exceptional woman was rarely mentioned in literary historiography. However, the last three decades produced a lot of writing about her, especially in Anglo-American literary historiography and in feminist approaches. Rekindled interest in women's role in the literary culture of early modern Europe revealed that there were more educated women than previously believed, especially in Italy, and that Cassandra Fedele was definitely one of the best known. Martin Lowry's words about Fedele in his famous monograph on Aldo Manuzio and the beginnings of printing can serve as a final illustration of Fedele's youthful reputation. In his chapter on the academic and scholarly life of Venice at the end of the $15^{\text {th }}$ century - which described the spread of humanistic studies and pointed out that interest in antiquity had become a matter of fashion, penetrating into wider society - Lowry says that all over Venice lectures and discussions about antiquity were being held. Those discussions sometimes took place under the gallery of the Doge's Palace or in the gardens, and sometimes during "a visit to the bewitching poetess Cassandra Fedele, whose recitations formed the centre-piece of Doge Barbarigo's public banquets, and whose very appearance reduced Poliziano to stammering helplessness". ${ }^{4}$ Since it was popular, almost a matter of prestige, to be in contact with Fedele, this was attempted by learned individuals from Dalmatia as well. Fedele's epistolary proved to be the most important for the topic of this paper, since two out of the three Dalmatians who are to be discussed exchanged letters with her. ${ }^{5}$

I have collected data on Dalmatian correspondents of Cassandra Fedele from different sources; most have already been published and discussed, however there are a few new and previously unknown ones. As was pointed out at the beginning, there have been periodic mentions

${ }^{4}$ Lowry (1979: 189). Poliziano's meeting with Cassandra Fedele which occured in 1491 in Venice, and his fascination with her are a well-known anecdote, described in almost all of the above-mentioned critical works on Fedele.

${ }^{5}$ I used the 1636 Padua edition of the epistolary in the Biblioteca Marciana in Venice. It is also available online: https://www2.uni-mannheim.de/mateo/desbillons/fedele.html. The epistolary was translated into English and Italian as well: Fedele (2000) and Fedele (2010). 
in scholarly literature of individual Dalmatians communicating with Fedele, but these observations have not been elaborated or interconnected, rather they remained fragmentary, only marginally noted in works on other topics. Today, however, the example of our Venetian author lets us see a network of intellectual ties and humanistic friendships, as well as all sorts of practical relationships between the two Adriatic coasts. Nevertheless, in the English edition of the epistolary edited by Diana Robin, Dalmatian humanists ended up among persons of whom nothing is known (in the chapter titled Unknown Correspondents and Humanist Form Letters, Fedele [2000], pp. 125-153). The Italian edition of the epistolary edited by Antonino Fedele (Fedele [2010]) gives no details about them either. I will not go deeply into the poetics of the epistolary texts here, the commonplaces of the genre or the humanistic themes discussed in the letters. Instead I shall focus on a few items from the content of letters important for Dalmatian authors.

The first Dalmatian correspondent of Cassandra Fedele was Benedikt Mišulić (Benedetto Missolo, Benedictus Missolus) from Pag, born around 1450 and died in 1509. Mišulić was a member of an eminent aristocratic family from Pag, a doctor of law from Padua, in his lifetime known as an astrologer and a military leader, since he was a galley commander in Venetian service. ${ }^{6} \mathrm{He}$ is referred to as a renowned Dalmatian by numerous older biographers and historians, for example by Daniele Farlati in the first volume of his ecclesiastical history titled Illyricum Sacrum (1751). He is also mentioned by his contemporary, a chronicler of the Venetian Republic, Marin Sanudo in his Diarii, mostly in relation to military expeditions in which the galley under Mišulić's command participated. All of them stress Mišulić's learnedness, the fact that he was a doctor of both canon and civil law, and a renowned astrologer, and he seems to have belonged to a humanistic circle which gathered in Zadar in the last quarter of the $15^{\text {th }}$ century around Deodat Venier, abbot of St. Chrysogonus monastery. ${ }^{7} \mathrm{Pal}-$ ladio Fosco (1450-1520), a humanist from Padua and a teacher in late $15^{\text {th }}$-century Dalmatia, in his De situ orae Illyrici, a geographical study dated cca. 1509, states the following about the island of Pag: "Ab Arba Septem millibus passuum distat Pagus ante Gissa appellata, quae circuitu Septingentorum stadiorum oppidum eiusdem nominis habet, patriam Benedicti Missuli Astrologiae, et Iuris tam Pontificii, quam Civilis scientissimi hoc ipso anno defuncti." ${ }^{8}$ Describing the coast of

${ }^{6}$ Knowledge of Mišulić is very limited, for basic data about him and his family see: Granić (1979) and Granić (2002), esp. pp. 69-72. See also Kurelac (1990: 46-48, 55).

${ }^{7}$ See Praga (1929: 144). Praga does not give sources for this information, while later Croatian historians do not state that they took it over from Praga.

${ }^{8}$ Immediately after that Fosco enthusiastically commends the taste of roast lamb from Pag: "Sed insula alioquin lapidosa aquis abundat, et ovillo pecore, agnique Pagenses, ut praepingues, saporisque optimi toto Illyrico laudantur"; see Fusko (1990: 108). In the Introduction to the edition mentioned in note 6, the year of Mišulić's death is 
Illyricum, Fosco does not mention local dignitaries often. For example, when he discussed Dubrovnik (on p. 104), of all Dubrovnik humanists and learned men of the age, he mentioned Ilija Crijević only (Aelius Lampridius Cervinus, 1463-1520).

Cassandra Fedele's epistolary holds a short letter written to Mišulić in 1490 (in the Tomasini edition from 1636, which remains the basic edition, it is numbered XXXI and titled Benedicto Missolo Pagano I. V. Consulto. Cassandra Fidelis. Epistolae tarditatem brevitatemque apud Benedictum Missolum excusat). It reveals that Mišulić wrote numerous letters to Fedele, though they have not been preserved. In it, Fedele apologises for a belated reply and the brevity of her letter, which is a frequent point in her letters to her correspondents. She also praises the style of Mišulić's letters, extols their friendship and stresses her current occupation with the Peripatetics. The letter does not contain anything especially interesting, yet seems to intimate, despite the conventionally expressed laudations, that Fedele and Mišulić were close, that their relationship was more than a humanistic friendship through correspondence. In Diana Robin's English edition of the epistolary Mišulić ended up in the index under $P$, because the editor in the expression Paganus did not recognize the town of Pag on the island of the same name, instead deeming it to be part of the addressee's last name. What is particularly interesting, and to date has gone unnoticed, is the fact that Cassandra Fedele mentioned Benedikt Mišulić in two other letters (Tomasini no. LXXXIV and no. LXXXV); the first is, in all probability, addressed to Pope Alexander VI, and the second to one of his close associates. Pope Alexander VI, the Spanish libertine Rodrigo Borgia, was the supreme head of the Catholic Church from 1492 to $1503 .{ }^{9}$ The two letters discuss equally Mišulić and the Pope;

wrongly stated (on p. 48), while the comments accompanying the text give an approximately correct date (p. 139).

9 The captions of those letters in the Tomasini edition do not name the Pope, they read Summo Pontifici, Summi Pontificis and a S. P., that is a Summo Pontifice. Antonino Fedele, the editor of the Italian edition of the epistolary, presumed that it is Paul III, to whom Fedele wrote in 1547 asking him to secure her financial assistance in her old age. When it comes to these two letters, such a thing is not possible as in them she talks about Mišulić who died in 1509, and the Pontificate of Paul III lasted from 1534 to 1549. The letters were, therefore, written much earlier. For reasons of chronology only Pope Innocent VIII, Alexander VI and Julius II can be taken into consideration, and Diana Robin concluded based on the context created by other letters by Cassandre Fedele and the events of her life, which primarily refers to the communication with the Spanish court, that the Pope in question is most likely the Spanish pope, which is what I believe, too. Still, considering letter LXXXV, I need to point out that it is, in spite of Robin's opinion, not directed to the Pope himself, but to some other unnamed, and to us unknown, dignitary who was obviously an arbiter among the Pope, Mišulić and Fedele, helping her obtain the Pope's gift. Above the letter where there should be the name of the addressee in the dative case, Tomasini's edition puts dots. Fedele addresses this dignitary on an occasion as "abs te Praeside dignissimo", while she refers to the Pope in the third person singular (ultimately, the inscription above the writing of the letter reads $O b$ impetratum a S. P. donum gratias agit). D. Robin interpreted this letter, too, as an address 
Mišulić is almost the centre of attention in them. It is not fully clear what is exactly being discussed, but the letters are devoted to thanking the Pope and his unknown associate for some big favour or gift, with Mišulić, as it appears, having played a decisive intermediary role. While Fedele, deeply touched, thanks the Pope for his favour (whose nature cannot be deduced from the letters; in the second letter Fedele also thanks an unknown third person), she takes the opportunity to praise Mišulić. She thus continually brings the Paganus into close relationship with the Pope, claims that it was he who brought her the Pope's gift, vouched for her before the Holy Father, is a loyal servant of His Holiness, an eminent lawyer, a serene knight, and endowed with many virtues and gifts of the spirit. This should open a new direction of research into Mišulić's life, as it becomes obvious that in the 1490s he resided in Rome in the service of the Pope, as a confidant. It may well be that the letters were a form of communication about Cassandra Fedele's attempts to obtain a position at the Spanish court, which is what she had aspired to for years. In order to achieve that goal Fedele was in contact with the Spanish royal couple Ferdinand II of Aragon and Isabella of Castile and their emissaries for some years, and when she finally succeeded in obtaining the desired service and was invited to their court, as the old biographers allege, she was forbidden to leave Venice by a decree issued by the Doge of Venice himself, wishing to assure that Venice does not lose one of its most famous attractions. ${ }^{10}$

The second Dalmatian who corresponded with Fedele was Ambroz Mihetić (Ambrosius Miches, Ambrogio Micheteo) from Šibenik who was born around 1415 , and died at the very end of the $15^{\text {th }}$ or at the beginning of the $16^{\text {th }}$ century, but definitely before 1508 . Mihetić was

to the Pope, while A. Fedele was more careful, concluding, rightly, that Cassandra addressed the Pope only in letter no. LXXXIV, though his judgement on the name of the Pope was wrong, while in letter no. LXXXV she addressed someone else mentioning therein Mišulić and Pope (the Italian translation of the letter is prefaced by A. Fedele's note Saluta il destinatario di cui non si conosce il nome, Fedele [2010: 289]).

${ }^{10} \mathrm{It}$ is possible that Fedele mentioned Mišulić in yet another letter, no. VI in the Tomasini edition. It is one of the four letters written to Filomuso from Pesaro, which is a humanistic name of Gianfrancesco Superchio (cca. 1440-1506), Sabellico's protege, teacher and cleric in Udine and Venice. Fedele commends Filomuso's discussion and argumentation skills, claiming, half in jest, that she is not afraid to enter into a discussion with anyone but him; not even learned Galeottus, nor eloquent Benedictus who deserves every praise, strike fear in her. In her commentaries to her edition of the epistolary, D. Robin (on page 99) claims that it is unclear who is being spoken of here, yet Tomasini in the notes to his edition (on page 213) refers to the identity of the persons discussed - he believes that Galeottus refers to the renowned humanist Galeotto Marzio (Galeottus Narniensis, cca. 1424-cca. 1495), connected with the Hungarian court and a close friend of Janus Pannonius, while Benedictus should refer to Mišulić. Should Tomasini's assumptions prove true, if Benedictus from the above letter should indeed prove to be Mišulić, it will mean that Paganus moved in the humanistic circles of Padua and Udine at the end of the $15^{\text {th }}$ century, and the comparison with Galeotto Marzio would be very complimentary for Mišulić. 
a member of an old and renowned aristocratic, pronouncedly pro-Venice oriented, family. He is an important early humanist from the circle of Juraj Šižgorić (Georgius Sisgoreus, cca. 1445-1509), one of the most important Dalmatian humanists, ${ }^{11}$ and on the whole, Mihetić is one of the most renowned and most influential people in Šibenik in the second half of the $15^{\text {th }}$ century. Among other things, he actively participated in important decisions relating to the construction of the Šibenik Cathedral. ${ }^{12} \mathrm{He}$ received a doctorate in liberal arts (artium doctor) in Padua in 1442 , in the third quarter of the $15^{\text {th }}$ century he was a Šibenik emissary to Venice, while in old age, he was a grammar teacher in Venice and Belluno. In the renowned book by Juraj Šižgorić Elegiarum et carminum libri tres (1477), the oldest poetic incunabula of Croatian literature, we find Mihetić's prose letter discussing Šižgorić's illness and celebrating his recovery. The middle of the letter carries verses from Virgil's Aeneid about rare souls which return from the afterlife, with Šižgorić having now joined their number. Šižgorić devoted two poems in the book to his friend Mihetić, in both titles referring to him as a philosopher (Ad Ambrosium Sibenicensem philosophum). The first one (III 1), an elegy, discusses his grave illness and recovery, while the second (III 8), in Sapphic stanzas, celebrates Mihetić as an expert in theology, philosophy and law, and praises his Latin oratory, or perhaps, prose written in Latin:

Doctor Ambrosi, Sibenica proles, patrie sydus probitate fulgens, te lyre nostre resonabo cantu:

Musa, faveto.

Tu dei veri celebrator almus, qui potens celsa volitans ab arce perditum mundum docuit sacrati lumina verbi.

Dicta sacrorum tibi sunt aperta, scripserat quicquid sacer ille Aquinas sive doctorum specimen minorum, Scotia proles.

Atque tu figis logycas sagittas et datas in te bene tu repellis, copia rerum penitus refulges philosophie.

${ }^{11}$ About Juraj Šižgorić see (items in English): Novaković (2000); Dukić/Grgin (2014); Jovanović (2015).

${ }^{12}$ See Marković (2010), especially pages 433-484. Marković's monograph offers not only information about Mihetić's role in the construction of the Šibenik Cathedral, but a useful synthesis of the knowledge we have on this humanist. For archival data on Mihetić's life see also Stošić (1936: 56); Grmek (1957: 356); Kolanović (1995); Pederin (1995); Čoralić (2003). For Mihetić see also Novaković (2014: 149 and 150) and Špoljarić (2018). 
Verba conscribis bene tu Latina

Tullio magno duce vel magistro et tibi, vir, sunt, celebrande, leges Iustiniane.

Tu faves nostris, venerande, Musis et dies longos mihi tu precaris, pro quibus pinguem iugulas iuvencam atque bidentem.

Pro tuis oro meritis poeta, sit tuo foelix Lachesis vigori, saeculum post hoc videasque campos Elysiorum. $^{13}$

Also preserved is a congratulatory oration given by Ambroz Mihetić in 1458 in Venice before the Doge Pasquale Malipiero; we further know that Mihetić copied humanistic manuscripts, in particular the Latin orthography handbook by Italian humanist Gasparino Barzizza. It can be assumed that Mihetić did not stand out as a poet, since Šižgorić persistently referred to him as a philosopher, and in the second poem devoted to him wherein he celebrates Mihetić's learning and cultural competencies, Šižgorić only marginally mentions Mihetić's poetry at the beginning of the last stanza, in an almost formulaic manner: "Pro tuis oro meritis poeta, / sit tuo foelix Lachesis vigori, / saeculum post hoc videasque campos / Elysiorum." If Mihetić had made his name by writing poetry, Šižgorić would definitely have mentioned it.

Cassandra Fedele's epistolary holds one letter by Mihetić (Tomasini no. XCV) and Cassandra's reply (Tomasini no. XCVI). Mihetić's letter identifies the sender as follows: Ambrosius Miches Dalmata et Sebenicensis and is dated January 1487, meaning that it was written before Fedele made a name by having given a speech in honour of her relative at the university in Padua. It is one of about twenty letters not written by her which have been preserved in her epistolary. It is not in the least surprising that it was chosen for preservation as it is ambitious, very interesting and quite long. And, of course, very laudatory for Fedele. In it Mihetić who, as he states himself, does not know Cassandra personally, and who is much older than her, amply demonstrates his humanistic erudition. At the beginning he informs Fedele that her fame has reached distant Dalmatia and does not spare praise of the young scholar and, by extension, of her homeland Venice. He points out that with her learnedness Fedele has beaten nature and overcome her sex, which was a common topos in the attempts of male humanists

13 Šižgorić (1966: 118 and 119). The poem mentions the following persons of authority: Thomas Aquinas, Duns Scotus, Cicero and Justinian the Great, as a codifier of Roman Law. On the relationship between Šižgorić and Mihetić it is still useful to refer to Šrepel (1899), especially since nothing newer has been written on the topic. 
to conceptualise the achievements of female spirit, to explain them to themselves in a way which would enable them to commend women. Namely, women were condemned by their sex to traditional social roles in which intellectual pursuits were undesirable. The sphere of intellect was reserved for men, which meant that a woman desiring to become intellectual should, in some way, cease being a woman, overcome her inferior nature and curb her female sexuality. ${ }^{14}$ Next, in order to make a comparison favourable for Fedele, Mihetić lists educated women of $15^{\text {th }}$-century Italy such as Constanza Varano, Ippolita Sforza, Battista Malatesta and Isotta Nogarola. He then brings in a catalogue of learned women from antiquity including Cornelia, mother of the Gracchi, Hortensia the Orator, Sappho and Aspasia, describing why each of them was exceptional, and finally points out that Fedele has caught up with them in fame. Although he brings together the learned women of the past and women warriors, such as the Amazons or Camilla from Virgil's Aeneid, Mihetić deems that the life of spirit convincingly exceeds bodily virtues, which he corroborates by citing Lactantius and Cicero. Catalogues of famous women of antiquity in works by European humanists are generally taken over, directly or via mediation, from Boccaccio's De mulieribus claris as well as from Plutarch's works. All examples given by Sebenicensis appear in a more comprehensive list in one letter by Poliziano to Cassandra (Tomasini no. CI). Mihetić's letter abounds in praises of intellect, acquisition of knowledge and liberal arts, only to alleviate this fervent humanism at the end of the letter by fusing it with the Christian doctrine ("et thesauros sacrarum scripturarum ad alias bonas literas, quas habes adiunge"), even in the final salutation ("Vale felix in Domino, et pro nobis ora"). In the middle of the letter Mihetic has again, just like in the letter published in Šižgorić's book, inserted verses, namely the following two: "Musa tibi vocem dedit, et Cyllenius artem, / Iupiter ingenium magnus Apollo chelim". Whereas previous commentators and editors of the epistolary did not uncover the origin of these verses, they are actually the adapted beginning of the epitaph for a Neapolitan poet written by Antonio Beccadelli (1394-1471) called Panormita, a wellknown Neapolitan humanist. In Beccadelli's epitaph the dead poet speaks of himself in a simulation of an epitaph:

Musa mihi vocem dederat, Cyllenius artem,

Iuppiter ingenium, magnus Apollo chelyn.

Tuscia me genuit, teneram Phanetida lusi.

Dux Ligurum rapuit. Hoc ego claudor, Hylas.

while in Mihetić's adaptation of these lines the lyrical subject speaks to Fedele, explaining to her which god gifted her with which gift (Muse gave her voice, Mercury gave her skill, and Jupiter gave her intellect,

${ }^{14}$ See King (1976); King (1980); Jardine (1985); Robin (1995). 
while Apollo gave her the lyre). ${ }^{15}$ Should special significance be given to the fact that Panormita was primarily known for his collection of erotic and obscene epigrams titled Hermaphroditus? Did Mihetić by reaching for his verses wish to give erotic charge to the message sent to Fedele? Presumably not. Beccadelli's epitaph is neither an erotic nor a lascivious poem; it is not included in Hermaphroditus, and it is questionable which author it was associated with by Mihetić and the then readers, since from its inception it circulated in manuscripts of whose authorship we are unsure. Humanistic and Renaissance poetry in general commonly borrowed paragraphs from extraneous texts for the author's own purposes, without much concern for the original context from which the utterance was taken. As for the response to Mihetić's letter, Fedele begins it, while apologizing for a belated reply, by explicitly saying that she is receiving too many letters to be able to reply to all, that numerous admirers besiege her, not giving her peace, wishing to have learned conversations with her. Fedele insists on humanistic friendship between her and Mihetić and conceives her reply completely on the father-daughter relationship, stressing that she expects fatherly love and care from the Sebenicensis, while she will behave as his dutiful and diligent daughter. While such a concept is in this case probably connected with a big age difference - which Fedele might have somehow learned about, although it is not expressly mentioned in the letters - it is also her usual rhetorical strategy, one she employs in other letters, as well. It seems that the purpose of such discursive stylisation was complete desexualisation of a relationship between a young educated woman and older, experienced men she exchanged letters with; namely, it was an attempt to preclude even the slightest idea of the inappropriateness of this, according to the then standards, very unusual relationship. ${ }^{16}$

The third Dalmatian who addressed Cassandra Fedele was Pavao Paladinić (Paolo Paladini), poet and humanist from the island of Hvar in the second half of the $15^{\text {th }}$ century. Little is known of his life, not even the exact years of his birth and death are known. He was most likely born after 1450 , and died early in the $16^{\text {th }}$ century, definitely not long after 1510 when he was still referred to as living. He was a member of an eminent aristocratic family from Hvar and a commander of a Hvar galley which participated in Venetian military expeditions at the end of the $15^{\text {th }}$ century. Vinko Pribojevic (Vincentius Priboevius, cca. 1480-after 1532), a Dominican priest from Hvar in his speech De origine successibusque Slavorum (delivered in 1525 in Hvar, printed in Venice in 1532) remembered Paladinić precisely for his

${ }^{15}$ Since I did not manage to acquire a printed edition of this little known poem by Panormita, I have taken over its text from the Perseus Digital Library web page (http://www.perseus.tufts.edu/hopper/). There the epitaph titled Hylas Pratensis, stands among Beccadelli's poems in the unit titled Humanist and Renaissance Italian Poetry in Latin.

${ }^{16}$ See the works in note 14 and especially Ross (2007). 
military courage, not for his writings. Fighting for Venice all over the Mediterranean, Paladinić met numerous renowned persons to whom he later devoted his poetry. His collection of poetry, dated 1496 and dedicated to Frederick of Aragon, the last king of Naples, was preserved in manuscript and recently discovered in Valencia. It was published by the Italian Slavicist Sante Graciotti, accompanied by an extensive and informative foreword. ${ }^{17}$ The collection contains a prose panegyric in Latin to Frederick of Aragon and 34 poems, half of which are in Latin, in elegiac couplets, while the other half are sonnets in Italian. Poems in Latin alternate with poems in Italian, with odd ones being in Latin, even ones in Italian. It is neither accurate nor appropriate to refer to Paladinić as a Petrarchist poet exclusively, as Graciotti does already in the title of his edition (Il petrarchista dalmata Paolo Paladini e il suo canzoniere). Above all, Paladinić's poems in Latin do not have anything in common with Petrarch nor with the theme of love, and only half of those written in Italian are love poems, which means that only a quarter of the collection can be called love lyrics, predominantly Petrarchan. Most of the poems are occasional, devoted to Venetian military commanders, dignitaries or humanists. What is particularly interesting, one is devoted to a well-known Dubrovnik humanist Ilija Crijević; the collection also holds laudatory poems written to Paladinić by Frane Božićević (Franciscus Natalis, 1469-1542), a renowned humanist from Split, Ilija Crijević, Tideo Acciarini and Pietro Contarini. One of the most renowned addressees in the collection is definitely Cassandra Fedele. Poem no. IX from Graciotti's edition is devoted to her:

\footnotetext{
Ad Cas[s]andram Fidelem

Veneta[m] virginem et vate[m]
}

Forma deae quam Cyprus amat neglecta iacet; nunc

Nobile et inuicte Palladis ingenium

Miratur meritosque tibi dat uulgus honores,

Quantos credibile est ante tulisse deas.

Perdit ars, miseras, hoc perdidit ante puellas;

Tam pia uerba solent impia facta sequi.

Inde magis tenues iam texit Aranea telas

Versaque sunt rauco suauia verba sono.

Propterea innumeros fertur perpessa labores

Cuius non faciem pertulit Alma Venus.

Doctior at quanto es tantoque potentior, aude,

Diceris Ausoniae Musa nouella lyrae.

${ }^{17}$ Graciotti (2005). Graciotti's introductory study titled La vita e l'opera di Paolo Paladini, on pages 9-119, analyses different aspects of the collection in full detail, from literary influences which can be traced in it to its historical context. It also gives a useful summary of the little existing literature there is on Paladinic and his family. In addition to the Introduction, on Paladinić see also Graciotti (2006) as well as Maroević's review of Graciotti's book (2005). 
Quare ego thespyadum suffragia prisca sororum

Ascraeo linquam Maeonioque seni.

Te mea charta ciet mihi, te dictante Poetam

Me Rhodus et Colophon, et uolet Ascra suum.

This time, then, it is a poem, not a letter that has been preserved in an epistolary. We do not know whether Paladinić knew Cassandra Fedele in person, or whether she responded to these verses; neither seems likely. With a number of motif references to classical culture and with ample use of the mythological instrumentarium, the poem establishes a polarity between two goddesses, Venus and Minerva, i.e., between poetry and knowledge. Instead of beauty, it is learning and intellect which enjoy accolades; Fedele is an example of Minerva beating Venus. Graciotti believes that the poem is slightly jocose, or ironic, since the lyrical subject, in his opinion, seems to regret Venus's defeat, claiming that Fedele has mastered sciences and their arduous tasks because Venus did not burden her with her gifts, which was supposed to mean that she was not beautiful. I am not sure there is anything sarcastic in such emphasis on the predominance of Pallas Athena over Venus. Such claims, common in the late $15^{\text {th }}$ century in the attitude of male humanists towards educated women, portrayed a learned woman as separated from her sex; she is desexualised. As was mentioned above - learned women, by becoming learned ceased being women in a way. Negating Venus usually functioned as a praise of intellect, since if a woman was learned, she must have belonged to Minerva, not to Venus. In order for female intellect to be praised, Amor and Venus have to be discarded, hence it is little wonder that educated women were often stylised as warriors or as a combination of Athena and an Amazon, a combination of virtue, virginity and wisdom (the title of Paladinić's poem reads "virginem et vatem"). In any case, if Paladinić is ironic, and if his irony is a form of disapproval of the sudden arrival of educated women on the cultural stage, something previously unimaginable, such disapproval functions within the framework of the then accepted relationship toward transgressive phenomenon of female learnedness. Additionally, I shall here briefly mention that certain contemporaries and witnesses praised the appearance of this young Venetian humanist, such as for example Angelo Poliziano, although stressing her integrity and natural simplicity of her beauty on the occasion.

There are other individuals who contributed to the creation of Cassandra Fedele's epistolary or were connected with her and the destiny of her oeuvre, and are in one way or another linked to the Slavic world on the eastern coast of the Adriatic. The 1636 Padua edition of the epistolary contains (on page 151) a laudatory Sapphic poem by Franjo Niger (Franciscus Pescennius Niger Venetus Liburnus, 1452-after 1523), taken over from an incunabula containing a speech Fedele gave at the university in Padua in 1487 for her cousin Bertuccio Lamberti. Pescennius was a Venetian humanist; he was not born in Dalmatia, but 
was of Slavic descent, his father was a Slav from Senj, as Niger liked to point out. The editor of the Padua edition of the epistolary Giacomo Filippo Tomasini (1595-1665) spent the last part of his life as a bishop in Novigrad, Istria, and died there. He is one of the most important polyhistors of the Italian $17^{\text {th }}$ century; he wrote an extensive, encyclopaedic scholarly work about Istria in eight volumes (De Commentari storici geografici della Provincia dell'Istria, libri otto, 1641) which also contains a lot of material about the Slavic element in the history of Istria. Furthermore, in the Introduction to the epistolary Tomasini (on pages 44 and 45) claims that the estate of Cassandra Fedele, and thus perhaps a part of her epistolary, fell into the hands of Juraj Dubrovčanin (Georgius Raguseius, after 1550-1622), a renowned university professor in Padua, a philosopher and a theologian, an Aristotelian. Thus we can discern a network of people from the eastern coast of the Adriatic around Cassandra Fedele. The three authors discussed above may not have been great writers, but they deserve far more attention than they have been given previously and not just because of their connection to Fedele. They each deserve at least an entry in lexicons and handbooks on the culture of the early modern period in Croatia, which they were denied in the past.

Finally, I would like to report briefly on an author whose presence among the correspondents of Cassandra Fedele I was not able to confirm, although I placed high hopes on it. This failure, however, brought other fruit. Namely, the addressee of two short letters by Cassandra Fedele (Tomasini no. XXII and no. XXIII) is a certain Bernardus Pinus. The letters themselves do not reveal much, other that Pinus was sending Fedele letters and poems, and that she was, as usual, late in replying, for which she apologised. In Diana Robin's edition and in the texts of more recent commentators the Pinus in question ended up among the addressees of whom nothing is known. While examining the manuscript legacy of Giuseppe Praga, Italian literary historian and renowned expert in Dalmatian cultural history, in the Marciana in Venice, I noticed that he copied these two letters from Cassandra's epistolary (in a volume with call number It. VI, 542 [12336], on sheets 155-160), and Praga would record only the things he believed had something to do with Dalmatia, rarely making mistakes. In addition to the two letters referred to above he also copied Cassandra's letters to Mišulić and Mihetić, as well as Mihetić's letter to Cassandra. Praga did not leave an explanation as to why he copied the two short letters to Pinus, but I soon realised that there can only be one reason for it - he believed that the addressee was Bernard Pima, an important and somewhat mysterious humanist from Kotor, a poet celebrated as poeta laureatus at the Roman academy of Pomponio Leto, which was an honour awarded to only two other Dalmatians of the day: Ivan Polikarp Severitan (Joannes Barbula Pompilius, 1472-around 1526) and Ilija Crijević. Pima's entire oeuvre is lost, only four laudatory verses (titled Bernardi Pimae Delmatae tetrastichon in laudem Domici Palladii Sorani) 
published in 1498 in Venice in the book by Domizio Palladio titled Domici Palladii Sorani epigrammaton libelli. Libellus elegiarum. Genethliacon urbis Romae have been preserved. Additionally, it is believed that Pima himself wrote a couplet in Latin which is the epitaph on his grave in Kotor. The exact year of his birth remains unknown; it was probably around 1450 , while he died around $1517 .{ }^{18}$ It seemed to me that shedding light on unknown literary activities of this humanist from Kotor, or at least disclosing some indirect information about his activities, might be a worthwhile result of the study of Cassandra Fedele and her Dalmatian correspondents. I have assumed that in the address of the first letter the addressee's last name was corrupted (from Pima to Pinus) which is obviously what Praga believed, too, so I tried to reinforce the assumption. Unfortunately, long examination did not turn up convincing arguments to support it. Not only was I unable to prove beyond all doubt that the addressee indeed is Pima of Kotor, but it seems that there are better candidates for the addressee of the two short letters by Cassandra, among them Bernardo Pino, a certain Canon and doctor of law from Bologna. However, following the logic of corruption of last names, I discovered two poems by Pima, thus far unknown, in a manuscript in the Marciana. They probably went unnoticed precisely because Pima's last name in the heading of the first was corrupted (from Pima to Pinia), yet other data in the titles and content of the poems should not leave doubt that their author indeed is Bernard Pima of Kotor. I am referring to manuscript Lat. XII, 211 (4179), with the poems being on pages 27 recto and 27 verso. This is an extensive $16^{\text {th }}$-century manuscript with almost 300 sheets, a miscellanea of Latin poems and letters by numerous authors written by several scribes, one of which is the above-mentioned Venetian chronicler Marin Sanudo. The first poem is prefaced with Ode monocolos Bernardi Piniae poete laureati, with the first two lines being: "Ioannes Decimi primus in atrio / est, omnes resonant Lascaros Eritheo". The second poem is prefaced with Alia eiusdem ad Leonem X. Pontificem, with the first two lines being: "Quo pastor Decimus totius est Leo / orbis, quo Medices tempore barbarus". Both texts were clearly written to commemorate the election of Giovanni Medici as Pope Leo X, which happened in March 1513, late in Pima's life. The election of Pope Leo $\mathrm{X}$ also awoke the interest of Marko Marulić (Marcus Marulus, 1450 1524) the best-known Dalmatian humanist, who devoted three epigrams to this event of great importance for the Christian world. While the corrupted form of the last name Pinia may not seem plausible, the expression of the lyrical subject from line seventeen of the second poem "sic ego Delmata" testifies to the fact that Bernard, the poet laureate, is precisely Pima from Kotor. ${ }^{19}$ The same manuscript from the

${ }^{18}$ For very scant information on Bernard Pima see Kovijanić (1953: 51, 52); Kovijanić (1970: 102, 103); Pantić (1990: 11-13); Kovijanić (2007: 159, 160).

${ }^{19}$ Paul Oskar Kristeller in his well-known catalogue of humanistic manuscripts titled Iter Italicum intimated that last name Piniae actually hides Pimae, as is evident from his 
Marciana contains a number of works by other authors of interest for our topic. There are, for example, poems by Domizio Palladio (around 1460-around 1533), a humanist whose real name was Domenico Farina; his 1498 incunabula contained the four laudatory verses by Pima referred to above. One of Palladio's poems is also devoted to Leo X, and in the codex immediately precedes those by Pima. At the beginning of the codex there are verses by Giovanni Perlotto, a humanist who in the early $16^{\text {th }}$ century wrote a Latin prose chronicle about military ventures by Pavao Paladinić and his father Nikola; this was published by Graciotti as an addendum to his edition of Paladinić's collection (Graciotti [2005], Historiola, pp. 183-197). Ultimately, the discovery of two previously unknown poems by Pima seems to be more worthwhile than the potential confirmation of Fedele writing him two short letters would have been.

Thus, at least for a moment, by way of little known or completely unknown sources, the characters of the famous late $15^{\text {th }}$-century Venetian female humanist's Dalmatian correspondents have emerged from oblivion. Persistent and thorough research might in the future yield similar discoveries about the attitude of Cassandra Fedele toward the eastern coast of the Adriatic and her contacts with early Dalmatian humanists.

description of the manuscript Lat. XII 211 (4179) where next to folio 27 stands "Bern. Pinia (or Pima, 27v)". However, nothing else is said as to who Pima, to whom Pinia refers, from the brackets is; see Kristeller (1998: 261). Additionally, Kristeller did not notice that the manuscript holds two poems by Pima in succession, instead mentioning only one, presumably the first. In a special volume with the index of names to Iter Italicum there is also a reference "Pima see Pinia", see Kristeller (1997: 428). 


\author{
APPENDIX \\ Clarissimae feminae Cassandrae Fidelis Venetae epistolae et \\ orationes posthumae, nunquam antehac editae, Padova 1636.
Benedicto Missolo Pagano I. V. Consulto. CASSANDRA FIDELIS.
Epist. XXXI. \\ Epistolae tarditatem brevitatemque \\ apud Benedictum Missolum excusat.
}

Plures tuas expectabam literas, ut meas quoque legere posses. Sed diu me expectasse censeo, tuisque ornatissimis ac copiosissimis respondere mihi visum est. Erat quidem summae benevolentiae crebras ad me literas mittere, cum ad te scribere impedimenta negarint, et nec materia plura mihi scribendi relicta sit. Nam innumeras fere ad innumeros literas dare mihi necesse fuit. Inquies forsitan: Cur cum tibi dicendi exuberantia succurrebat, non ad me quoque scriberes. Cur ais? Nam inane scribere arbitrabar. Nec aedepol tuam inire amicitiam opus erat. Ea est enim adeo inter nos singularis, ut nihil addi possit. Nec mihi te laudare datum est. Tuae medius fidius amplissimae ac divinae dotes quaecumque vel consummatissimum defatigarent oratorem. Meorum igitur literarum tarditatem ex his facillime cognosces, nec non earum brevitatem. Magna sane Peripateticorum copia me avocat. Vale; nos tibi commendamus. V. Idus Septembres a primo aevo Olympiade XXXCCCLXXXX. 


\section{SUMMO PONTIFICI}

CASSANDRA FIDELIS. Epist. LXXXIV.

Summi Pontificis laudes, cuius munificientiam fuerat experta.

Largita esse ab antiquis de clementia multa, Beatissime Pater, nemini dubium est, quae unum in locum collecta cum hoc tuae sanctitatis munere nullo modo comparari posse video. Nam si ii, de quibus ea traduntur caeteris quoque virtutibus praediti fuere, et tamen velut informes sine fide, qua tua sanctitas cum sanctissimis illis patribus contendit, iure optimo existimandi sunt; sin huic uni studuerunt, te praeclarissimis tuis facinoribus gestisque eos inferiores haberi necesse est. Quippe qui augustum illud tuo sacro pectore omnium virtutum consilium ad res deliberandas adducas. Duo itaque Beatissime Pater laudanda mihi forent, quae alioquin mea verba extenuant, ac ingenioli mei vires enervant. Hic tuae summae virtutes, quarum lumine, ac splendore omnes gentes, omnisque praestantium virorum memoria obtenebrantur, atque obteguntur. Inde divinum hoc munus tuum tanta pietate, munificentiaque in me collatum, et tam praestanti portitore Benedicto Misolo Pagano tuae sanctitatis devotissimo servulo iurisconsulto dignissimo; praeclarissimo equite, omnibus animi dotibus praedito, tuarumque laudum praecone. Quibus igitur verbis ad agendas gratias utar? Haud facile reperio, et quando de me pauca polliceri possum, cum nihil mihi sit. Sed Deum Optimum Maximum orabo, ut tuae Beatitudini vota fortunet, Vitamque ab omni corporis immunditia, ac vitiis immunem, et perennem liberet ac servet. 
CASSANDRA FIDELIS. Epist. LXXXV.

Ob impetratum a S. P. donum gratias agit.

Cum magnitudinem tuorum in me meritorum reputarem, non a me alienum existimavi his literis me tibi gratam ostendere, praesertim cum virtutibus nullis carere velim. Haec est enim virtus praecipua (ut reor) animi gratitudo, et eo gratior quod abs te Praeside dignissimo, et summa apud omnes auctoritate non minus me gratam esse quam videri malim. Nemo porro tam inhumanus, tam durus, tam ferreus, qui beneficiis acceptis non dignus, sed victus, vel invictus esse videatur. Tantum est itaque tuorum in me meritorum pondus, ut tibi me vitam debere concedam. Tu vero hoc divinum munus a Beatissimo Patre mei causa impetrare non dedignatus es, cum tantum de me Benedicto Missolo Pagano crederes. Iure quidem si eius, et maximas, et innumerabiles virtutes inspicias, quamquam ingenio non solum doctrinaque, verum etiam virtutum insignibus dignitatis, et eques, et iurisconsultus praestantissimus habetur, qui tuam profecto praestantiam, dignitatem, temperantiam, virtutesque tuas gloria, summaque laude ad coelum extulit. Is amari, amplectique dignissimus est. Reliquum illud est, ut existimes Cassandram tuarum virtutum studiosissimam, tuaeque opinioni, quoad poterit, pro ingenioli sui viribus responsuram, nulloque loco tuis laudibus defuturam. Qua propter memoria tui in me beneficii sempiterna. Tui animi magnitudini me totam commendo atque trado. Vale. 


\section{AMBRosius Miches \\ Dalmata et Sebenicensis. \\ CASSANDRAE FIDELI. S. P. D. \\ Epist. XCV.}

Cassandrae naturae et fortunae a dotibus praeconium.

Quod ignotus ad quasi ignotum scribam, Virgo Cassandra Fidelis, ne mireris. Rumor virtutum tuarum increbuit, et pulsavit aures nostras, et me tandem impulit inter alios eruditionem tuam tentare, ut saltem ex hoc nosse possis tui Nominis famam circum quaque spargi, et etiam procul ad Provinciam nostram penetrasse, nec intra proprios parietes comprimi posse. Nam ea de te et tuo studio praedicantur celebranturque, quae non solum in foemineo sexu, verum etiam in virili stupore forent. Magna vis Virtutis est atque doctrinae, ut in quocumque loco sit, latere non possit nomen tuum. Multa te commendant Virgo egregia: excellens in orbe terrarum Patria, Urbs inclyta Venetorum, Ingenium, Parentes, Dii tibi formam, Dii tibi divitias dederunt. Sed in his multos communes habes; Ingenio autem, ac eruditione liberali paucos, quibus Patriam tuam irradias insuper et parentes tuos illustras, qui si minus hactenus cogniti fuerunt, per te magis fulgebunt.

Musa tibi vocem dedit, et Cyllenius artem, Iupiter ingenium magnus Apollo chelim.

Has autem dotes ineffabili studio auxisti, superasti sexum, vicisti naturam, coaequasti te non solum nostri seculi egregiis ac illustribus Virginibus, ut fuit D. Costantia [...] Sfortia, D. Baptista de Malatestis, D. Isota Nogarola Veronensis, quarum circumferuntur Orationes et Epistolae in prosa et carmine luculentissimae. Verum ad earum gloriam accessisti, quae priscis seculi $<\mathrm{s}>$ decori et ornamento fuerunt, ut Romanorum tempore Cornelia Mater Gracchorum, quae non parum contulit filiis suis ad eloquentiae copiam et leporem: Hortensia item filia Hortensii summi oratoris in sinu patris enutrita, quae prae aliis eloquentia floruit, et causam Matronarum in curia egit cum magna auditorum admiratione. Huic accedit Sapho Poetissa, quae carmine suo omnibus seculis futuris se celebranda dicit. Nec tacetur Aspasia Socratis tempore doctissima foemina. Puto, non te futura secula silebunt, intendisti animum tuum bonis artibus, et non lanificio muliebri, aut operi mechanico. Nam iuxta Lactantium Firmianum in tenebris et morte versabuntur, qui animi bona negligunt, et corporis amplectuntur. Fuerunt Amazones bellatrices, et Camilla Virgo bellatrix, eae ausae in certamine bellorum cum viris concurrere, tamen maiorem laudem esse duco cum viris non corpore aut manu, verum etiam animo, ac peritia bonarum literarum certare, ut tu soles Virgo felix, et famam non vi corporis, sed virtute animi quaerere, in quibus rebus excellere, (ut Cicero noster testatur) pulchrum 
et laudabile putamus. Nihil enim conducibilius, nec magis frugiferum, quam posthabitis corporis commodis ad ea niti summo studio, quae fortuna labefactare non potest, et ad Virtutum apices pervenire. Quo circa qui te non laudat, et in numero laudabilium Virginum non reponit, ipse illaudabilis est. Perge ergo Virgo Fidelis ut caepisti, et fac istud nomen quod generis et prosapiae est, ut etiam Virtutis sit, et vere sis Fidelis et re et nomine, et thesauros sacrarum scripturarum ad alias bonas literas, quas habes adiunge. Ut cum lampadibus quas habes etiam oleum habeas, quod ex sacris exprimitur eloquiis, et cum prudentibus Virginibus computeris, et ut accipiaris a Domino. Vale Felix in Domino, et pro nobis ora. Sibenici, M.CCCC.LXXXVII. Prid. Id. Ian. 
CASSANDRA FIDELLIS.

AMBR. Miches EXCELlENTISS. DOCT. S. D.

Epist. XCVI.

Scriptionis tarditatem excusat propter occupationes literarias, seque commendat.

Nomine negligentiae a te dignissimo Viro accusari non dubito, cum ad respondendum tardiuscula tuis ornatissimis literis fuerim. Sed malo tarditatis culpam agnoscere, quam apud te negligentiae suspecta esse. Posteaquam me a teneris annis ad literarum studia contulissem, et ad me literae tam crebro afferantur ut, a componendo desistere nequeam, et intra meos parietes dignissimis continue viris circumdata sim, tum mei visendi, tum etiam disputandi gratia. Haec igitur me tardiorem fecerunt. Quare te oro, ne Cassandram tuam benevolentiam spernere existimes, sed quoad vivam maximo amore prosequor. Non mediocris igitur mihi cura adhibenda est, ut tantae vim necessitudinis ostendere possim. Quare a te peto, ut me in tuorum caeterorum amicorum numero collocare velis. Quid me benevolentiam suscipere, dixi? Ut te tantum, ac talem Virum, et ob aetatem Virtutesque maximas in amicitia postulem. Idcirco te obsecro, ut me paterno amore prosequaris. Ego enim te non secus ac patrem amo, et observo. Manda igitur, impera filiae Cassandrae: iussa capessere filiae erit. Quod me usque ad sidera extollis, minime mirandum est. Paterno enim officio functum fuisse cognovi. Filiam literarum studiis incitatam laudibus inflammas. Ecquid autem filiola mea? inquies. Semper quidem, sed tuae me laudes incenderunt. Quare tibi ingentes ago gratias, meque paterno amore diligas oro. Vale. Venetiis K1. Maias Anno sal. M.CCCC.LXXXVII. 


\section{BIBLIOGRAPHY}

Cavazzana, Cesira. 1906. Cassandra Fedele erudita veneziana del Rinascimento. Ateneo Veneto, 19, 2, 73-91, 249-275 and 361-397.

Čoralić, Lovorka. 2003. Šibenčani u Mlecima. Šibenik : Gradska knjižnica „Juraj Šižgorić".

Dukić, Davor/Grgin, Borislav. 2014. Juraj Šižgorić and the Ottomans: the Image of the Other in a Late Medieval Dalmatian Commune. Association Internationale d'Études du Sud-Est Européen. Revue, 40-44/2010-2014. Bucarest: AIESEE, $97-112$.

Fedele, Antonino. 2010. Cenni biografici introduttivi. Fedele, Cassandra. Orazioni ed epistole [trans. and ed. Antonino Fedele]. Padova : Il Poligrafo, 27-46.

Fedele, Cassandra. 2000. Letters and Orations [trans. and ed. Diana Robin]. Chicago-London: The University of Chicago Press.

Fedele, Cassandra. 2010. Orazioni ed epistole [trans. and ed. Antonino Fedele]. Padova : Il Poligrafo.

Fusko, Paladije. 1990. Opis obale Ilirika - De situ orae Illyrici [trans. and ed. Bruna Kuntić-Makvić]. Zagreb : Latina et Graeca.

Graciotti, Sante. 2005. Il petrarchista dalmata Paolo Paladini e il suo canzoniere (1496). Rim : Il Calamo.

Graciotti, Sante. 2006. Jedan gotovo nepoznat dalmatinski petrarkist: Paolo Paladini. Petrarca i petrarkizam u hrvatskoj književnosti. Zbornik radova s međunarodnog simpozija održanog od 27. do 29. rujna 2004. u Splitu [ed. Bratislav Lučin and Mirko Tomasović]. Split : Književni krug, 57-67.

Granić, Miroslav. 1979. Tri soprakomita paške obitelji Mišolić. Zadarska revija, 28, $2-3,283-290$.

Granić, Miroslav. 2002. Paški grbovnik. Split : Književni krug.

Grmek, Mirko Dražen. 1957. Hrvati i Sveučilište u Padovi, Ljetopis JAZU, 62, 334374.

Jardine, Lisa. 1985. 'O decus Italiae virgo', or The Myth of the Learned Lady in the Renaissance. The Historical Journal, 28, 4, 799-819.

Jovanović, Neven. 2015. Juraj Šižgorić. Christian-Muslim Relations: A Bibliographical History. Volume 7. Central and Eastern Europe, Asia, Africa and South America (1500-1600) [ed. David Thomas and John Chesworth]. Leiden-Boston : Brill, 31-35.

Jovanović, Neven. 2017. Croatian Neo-Latin Literature and Its Uses. A Handbook to Classical Reception in Eastern and Central Europe [ed. Zara Martirosova Torlone, Dana LaCourse Munteanu and Dorota Dutsch]. Chichester : WileyBlackwell, 35-45.

King, Margaret L. 1976. Thwarted Ambitions: Six Learned Women of the Italian Renaissance. Soundings, 59, 3, 280-304.

King, Margaret L. 1980. Book-Lined Cells: Women and Humanism In The Early Italian Renaissance. Beyond Their Sex: Learned Women of the European Past [ed. Patricia H. Labalme]. New York : New York University Press, 66-90.

King, Margaret L. 2014. Cassandra Fedele. Renaissance Humanism. An Anthology of Sources [ed. Margaret L. King]. Indianapolis : Hackett, 282-284.

King, Margaret L.; Rabil, Albert Jr. [ed.]. 1983. Her Immaculate Hand. Selected Works By and About The Women Humanists of Quattrocento Italy. Binghamton, N. Y. : Center for Medieval \& Early Renaissance Studies.

Kolanović, Josip. 1995. Šibenik u kasnome srednjem vijeku. Zagreb : Školska knjiga. Kovijanić, Risto. 1953. Которски пјесници-хуманисти. Сйварање, 8, 1-2, 51-61.

Kovijanić, Risto. 1970. Књижевност Котора. Койорска секиија Друшӣва исииоричара Црне Горе. Kotor : Društvo istoričara Crne Gore, 93-131. 
Kovijanić, Risto. 2007. Kotorski medaljoni. Perast : Gospa od Škrpjela.

Kristeller, Paul Oskar. 1980. Learned Women of Early Modern Italy: Humanists and University Scholars. Beyond Their Sex: Learned Women of the European Past, [ed. Patricia H. Labalme]. New York : New York University Press, 91-116.

Kristeller, Paul Oskar. 1997. A Cumulative Index to Volumes I-VI of Paul Oskar Kristeller's Iter Italicum. Leiden-New York-Köln : E. J. Brill.

Kristeller, Paul Oskar. 1998. Iter Italicum. Volume II. Italy, Orvieto to Volterra, Vatican City. London-Leiden-Boston- Köln : The Warburg Institute; E. J. Brill.

Kurelac, Miroslav. 1990. Paladije Fusko - Palladius Fuscus: život i djelo. Fusko, Paladije. Opis obale Ilirika - De situ orae Illyrici [trans. and ed. Bruna KuntićMakvić]. Zagreb : Latina et Graeca, 5-76.

Lowry, Martin. 1979. The World of Aldus Manutius: Business and Scholarship in Renaissance Venice. Oxford : Basil Blackwell.

Lučin, Bratislav. 2014. Litterae olim in marmore insculptae: Humanist Epigraphy on the Eastern Coast of the Adriatic until the Age of Marko Marulić. Classical Heritage from the Epigraphic to the Digital: Academia Ragusina 2009 \& 2011 [ed. Irena Bratičević and Teo Radić]. Zagreb : Ex libris, 23-65.

Marković, Predrag. 2010. Katedrala sv. Jakova u Šibeniku. Prvih 105 godina. Zagreb: Naklada Ljevak.

Maroević, Tonko. 2005. Osvit humanizma na Hvaru. Vijenac, 13, 302, 9.

Meyer, Ursula I. 2014. Humanistinnen. Aachen : ein-FACH-Verl.

Novaković, Darko. 2000. Neo-Latin Love Elegy in the Croatian Humanism: Tradition and Innovation. Slika antike u novovjekovlju / L'imagine dell'antichità nella ricezione moderna / L'image de l'antiquité à l'époque moderne / Das Bild der Antike in der Neuzeit / The image of antiquity in modern times. Zbornik radova s međunarodnog skupa, Zagreb, 2.-5. V. 1997. [ed. Olga Perić]. Zagreb : Latina et Graeca; Hrvatsko društvo klasičnih filologa, 1-20.

Novaković, Darko. 2014. Scribes, Scholars and Authors: The Beginnings of Humanism in Croatia. Classical Heritage from the Epigraphic to the Digital: Academia Ragusina 2009 \& 2011 [ed. Irena Bratičević and Teo Radić]. Zagreb : Ex libris, 147-168.

Pantić, Miroslav. 1990. Кюижевносй на йлу Црне Горе и Боке Койорске од XVI до XVIII века. Beograd : Srpska književna zadruga.

Pederin, Ivan. 1995. Šibensko društvo u drugoj polovici XV. st. Radovi Zavoda za povijesne znanosti HAZU u Zadru, 37, 249-293.

Pignatti, Franco. 1995. Fedele (Fedeli), Cassandra. Dizionario biografico degli Italiani, knj. 45. Rim : Istituto della Enciclopedia Italiana, 566-568.

Praga, Giuseppe. 1929. Lo 'Scriptorium' dell'Abbazia Benedettina di San Grisogono in Zara. Archivio Storico per la Dalmazia, 7, 39, 127-146.

Robin, Diana. 1994. Cassandra Fedele (1465-1558). Italian Women Writers: A BioBibliographical Sourcebook [ed. Rinaldina Russell]. Westport-ConnecticutLondon : Greenwood Press, 119-127.

Robin, Diana. 1995. Cassandra Fedele's Epistolae (1488-1521): Biography as Ef-facement. The Rhetorics of Life-Writing in Early Modern Europe: Forms of Biography from Cassandra Fedele to Louise XIV [ed. Thomas Mayer and Daniel Woolf]. Ann Arbor : University of Michigan Press, 187-203.

Robin, Diana. 2000. Editor's Introduction. Fedele, Cassandra. Letters and Orations [trans. and ed. Diana Robin]. Chicago-London: The University of Chicago Press, 3-15.

Robin, Diana. 2002. Cassandra Fedele (1465-1558). Women Writing Latin. Early Modern Women Writing Latin [ed. Laurie J. Churchill, Phyllis R. Brown and Jane E. Jeffrey]. New York-London : Routledge, 55-82. 
Robin, Diana. 2007. Fedele, Cassandra (1465-1558). Encyclopedia of Women in the Renaissance. Italy, France, and England [ed. Diana Robin, Anne R. Larsen and Carole Levin]. Santa Barbara-Denver-Oxford : ABC-CLIO, 137-139.

Ross, Sarah Gwyneth. 2007. Her Father's Daughter: Cassandra Fedele, Woman Humanist of the Venetian Republic. The Trouble with Ribs: Women, Men and Gender in Early Modern Europe [ed. Anu Korhonen and Kate Lowe]. Helsinki : Helsinki Collegium for Advanced Studies, 204-222.

Simonsfeld, Henry. 1890. Cassandra Fedele. Beilage zur Allgemeinen Zeitung, 48, 13 and $49,2-4$.

Simonsfeld, Henry. 1893. Zur Geschichte der Cassandra Fedele. Studien zur Litteraturgeschichte. Michael Bernays gewidmet. Hamburg-Leipzig : Verlag von Leopold Voss, 97-108.

Stošić, Krsto. 1936. Galerija uglednih Šibenčana. Šibenik : K. Stošić.

Šižgorić, Juraj Šibenčanin. 1966. Elegije i pjesme - Elegiae et carmina [trans. and ed. Nikola Šop]. Zagreb : Jugoslavenska akademija znanosti i umjetnosti.

Špoljarić, Luka. 2017. The First Dalmatian Humanists and the Classics: A Manuscript Perspective. A Handbook to Classical Reception in Eastern and Central Europe [ed. Zara Martirosova Torlone, Dana LaCourse Munteanu and Dorota Dutsch]. Chichester : Wiley-Blackwell, 46-56.

Špoljarić, Luka. 2018. Power and Subversion in the Ducal Palace: Dalmatian Patrician Humanists and Congratulatory Orations to Newly Elected Doges. Neo-Latin Contexts in Croatia and Tyrol: Challenges, Prospects, Case Studies [ed. Neven Jovanović, Johanna Luggin, Luka Špoljarić and Lav Šubarićc. Wien : Böhlau, 81-104.

Šrepel, Milivoj. 1899. Humanist Šižgorić. Rad JAZU, 138, 206-269. 
